\title{
The Northeast Asian Regional Security Complex: Japan-Russia Defense Relations
}

\author{
Anthony V. Rinna
}

\begin{abstract}
This paper addresses Japan-Russia defense relations in the context of Japan's defense policy shift regarding the reinterpretation of the Japanese constitution's Article 9, Russia's recalibration of its military forces in the Asia-Pacific, and the rise of Chinese military power in Northeast Asia. It argues that as Northeast Asia comprises a "regional security complex", the security relationship between Japan and Russia, is not solely contingent upon Moscow and Tokyo's handling of bilateral affairs. Rather, external factors that involve both Japan and Russia separately also affect this bilateral security relationship. Despite the Japanese and Russian governments' efforts toward improving bilateral defense relations in light of the Kuril Islands/Northern Territories dispute, Moscow and Tokyo's respective defense policies in response to the rise of China's military prowess in Northeast Asia also affect Japan-Russia defense relations. Specifically, Japan and Russia's buildup of their navies in order to counter the rise of China's maritime prowess may also cause military tensions between Moscow and Tokyo.
\end{abstract}

Keywords: China, defense, Japan, Russia, security

\section{Introduction}

After several years of relative neglect, the Russian Federation is attempting to re-assert itself as a major power in the Asia-Pacific region. This endeavor has been termed Russia's "pivot to the East". Despite Russia's previous relative lack of involvement in the AsiaPacific, the Russian Federation, due to the growing political and economic importance of the region as well as Russia's geographic presence, cannot afford not to become involved in East Asia, both economically and politically ${ }^{1}$. While cooperation with China consumes a great deal of activity in Russia's new Asia policy, Russia's "pivot to the East" is more multifaceted than a simple recalibration of China-Russia ties. The China-Russia relationship must contend with many potential setbacks in areas that are the ostensible foundations of this bilateral partnership, such as volatility in the two countries' bilateral energy relationship (due to declining Chinese demands of Russian energy supplies). Furthermore, the Sino-Russian relationship is becoming unequal in terms of the overall value-added of this arrangement in favor of China, and as time goes on the asymmetrical nature of the usefulness of the relationship will continue to grow, to the end that Russia will become an increasingly irrelevant partner for China ${ }^{2}$.

Moscow's relations with Tokyo, therefore, also comprise an important aspect of this Russian effort to augment its economic and political stature in the Asia-Pacific. This has been particularly true in the economic facet of their relationship, as the two sides have sought increased cooperation on commerce and trade. Russo-Japanese efforts at

\footnotetext{
${ }^{1}$ Yulia Sergeevna Lebeda, Spetsifika formirovaniya struktur bezopasnosti v Aziatsko-Tikhookeanskom regione: noviye vozmozhnosti dlya Rossii (Specifics of the Formation of Security Structures in the AsiaPacific Region: New Possibilities for Russia). Vlast 2, 2012.

${ }^{2}$ Bobo Lo, Ten Things Everyone Should Know about the Sino-Russian Relationship, Centre for European Reform, 2008.
} 
establishing increased intimacy between the two countries, however, must contend with a complicated defense relationship. The security relationship between the two countries remains marred by not only the ongoing Kuril Islands/Northern Territories dispute, but also an overall lack of strategic trust and communication on defense affairs between the two sides.

In addition to Russia's efforts to strengthen its ties with East Asian powers, Russia's "pivot" also entails a revival of its Asia-Pacific military forces with an end goal of securing its eastern territories against a number of potential security threats. Concurrent with Russian endeavors to recalibrate its military strength in the Russian Far East, Japan has undertaken a reinterpretation of its constitutional limits on participation in armed combat, as well as having approved the largest defense budget in recent years. Because Japan and Russia are geographically juxtaposed in a security environment that comprises security threats for both countries, Japan and Russia have responded by fortifying their military capabilities against these threats, including China's rising military prowess.

\section{Regional Security Complex Theory and Primary Institutions}

An appropriate theoretical viewpoint for understanding the nature of Japan-Russia security ties is the concept of "regional security". According to Stone, the scholarly study of regional security had not been sufficiently studied before the work of Barry Buzan in the English School of International Relations. Buzan describes regional security in terms of countries belonging to one or more "regional security complexes", whereby security between neighboring states in a limited geographic scope is inextricably linked to one another. In regional security, interstate considerations on security are not limited to balance of power considerations, but also include territorial disagreements ${ }^{3}$. If one considers not only geography but the rash of territorial disagreements, as well as strategic tensions stemming from issues such as regional militarization and missile defense, then it is reasonable to consider Northeast Asia as constituting a regional security complex. Buzan's inclusion of territorial disagreements in his attendant theoretical analysis of regional security particularly pertinent to Northeast Asia's security environment, and especially the China-Japan-Russia triangle, given Japan's territorial disagreements with both China and Russia.

Continuing with this analytical framework, the English School's views on international security portray international society as belonging to one of four "primary institutions", which Buzan defines as "deep, organic, evolved ideas and practices that constitute both the players and the game of international relations." The English School's four "primary institutions" that define interstate relations: power political, coexistence, cooperative and convergence. In the case of Japan-Russia defense relations, the bilateral ties between the two countries could best be described as being in a state of coexistence. Japan and Russia are sufficiently distinct and self-interested societies, both of which seek to retain their independent political and national characters. Russia in particular has exhibited the warlike characteristics that define coexistence between states (although significantly less so in Asia as it has in Europe), and both Japan and Russia have strong

\footnotetext{
${ }^{3}$ M Stone, "Security According to Buzan: A Comprehensive Security Analysis," Security discussion papers series, 1, 2009, pp. 1-11.
} 
nationalist undercurrents in both their political elites as well as their respective broader populations that make closer cooperation and convergence between the two sides difficult. Japan and Russia's security imperatives, many of which stem in large part from considerations outside their bilateral ties, will likely hold the two countries in a state of coexistence. This is because even if Japan and Russia are not primarily concerned with each other as their main potential or real security threat, the paths toward greater militarization in the Asia-Pacific on which the two countries have embarked will likely perpetuate at the very least an underlying current of mistrust and tensions.

\section{Tokyo's Defense Policy Shift and Moscow's Asia-Pacific Military Revival}

Since the return of Japan's Liberal Democratic Party to power in late 2012, the Japanese government has undertaken a series of measures to increase Japan's military posture. In July 2014 the Japanese Diet announced policy changes to its interpretation of Article 9 of Japan's post-WWII constitution. One of the biggest impetuses for the revised interpretation is the fact that Japan seeks to return to what has been designated as a "normal" status for an independent state, meaning the right to a fully capable defense apparatus and complete responsibility and sovereignty over its own security. Japan's defense posture has generally vacillated between the "Yoshida Doctrine", which entails a strong adherence to the principles of Japan's postwar defense alliance with the United States with a greater emphasis on economic development, and the "Nakasone Doctrine", which asserts a greater Japanese right to self defense and a more pronounced military posture.

Japanese lawmakers' altered interpretation of Article Nine's provisions expand the mandate of the Japan Self Defense Forces to operate within the framework of its existing defense relations with other countries. The revised interpretation of Article Nine, specifically, has subsequently led to changes in the framework of the Japan-US alliance, encapsulated in the U.S.-Japan Guidelines for Defense Cooperation. One of the biggest changes to Japan's defense policy as a result of the Article Nine reinterpretation as well as revisions in the US-Japan Guidelines is the permission for the Japan Self Defense Forces to participate in more globally-oriented training and operations, similar to the kind the US engages in with allies such as Australia and the Republic of Korea ${ }^{4}$. According to the Guidelines:

\section{The Self-Defense Forces will conduct appropriate operations involving the use of force to respond to situations where an armed attack against a foreign country that is in a close relationship with Japan occurs and as a result, threatens Japan's survival and poses a clear danger to overturn fundamentally its people's right to life, liberty, and pursuit of happiness, to ensure Japan's survival, and to protect its people.}

Concurrent with these policy shifts, the Japanese government has also overseen an increase in its defense spending. In 2016 the Diet approved a record-high USD 41.4 billion budget, preceded by spending increases in the previous years. Overall the portion of the

\footnotetext{
${ }^{4}$ Sasakawa Peace Foundation USA, "Collective Self Defense," 2015. Retrieved from: http://spfusa.org/research/collective-self-defense/ Accessed June 14, 2016
} 
Japanese GDP spent on the armed forces has consistently remained at around 1\%, which, according to figures from the Stockholm International Peace Research Institute, is approximately half of the amount of per capita GDP China has spent on its military, and one-and-a-half times less than South Korea's amount of per capita GDP spending on defense ${ }^{5}$. In 2015, China spent 215 billion dollars on defense, Russia spent 66.4 billion and South Korea spent 36.4. These three countries fell within the top ten highest spenders on defense in terms of dollar amount ${ }^{6}$. Yet despite the comparatively smaller Japanese budget appropriations on defense, Japan has specifically sought to increase the capabilities of its Maritime Self Defense Forces, which remains one of the most technologically advanced in all of Asia. For the 2016 fiscal year, the Japanese defense ministry released an expenditure plan that included the following measures: 24.4 billion yen on anti-submarine patrol helicopters; 63.6 billion yen for the construction of a new Soryu-class submarine and 3 billion yen for life extensions on four Oyashio-cass submarines; and expanding and improving upon fixed wing maritime patrol aircraft ${ }^{7}$.

Since 2010, Russia's East Asian military forces have undergone major shifts, such as a reorganization of the Russian military's Eastern regional command. A visit by Russia's defense minster Sergei Shoigu in February 2014 to Primorsky Krai brought to light the glaring deficiencies in Russia's East Asian defense capabilities, especially with regard to its navy. This was in part a consequence of post-Cold War reductions in Russia's Pacific maritime forces. From 1990 to 1997, the Russian Pacific Fleet reduced its submarine fleet by $54 \%$ and its surface ship fleet by $28 \%{ }^{8}$. Maritime security constitutes one of the biggest priorities for the Russian armed forces' Far Eastern Military District, for unlike some of Russia's other military districts, where the greatest threats to Russian security are in the form of land-based NATO troop concentrations and other potential forms of instability (although seaborne threats are also an important part of the other Russian military districts), the Russian Far Eastern area of military responsibility is where a number of oft-competing naval powers converge- China, Japan, South Korea as well as the US 7th Fleet. North Korea, while behind the others in both the qualitative and quantitative terms of its force capabilities, also boasts a formidable navy.

The main priorities for the Russian Navy's Pacific Fleet are to enact strategic deterrence as well as coastal protection in the form of access denial ${ }^{9}$. The two keystones of Russia's naval strategy in Northeast Asia are the creation of multilateral security arrangements based on confidence building, as well as a reduction of the size of Russian defense forces in exchange for more lethal and effective weaponry ${ }^{10}$. Russia's enhancement of its Pacific Fleet also entails manifold technical upgrades and expansions of its fleet capabilities. On the one hand, it has begun to outfit its Asia-Pacific fleet with Fifth

\footnotetext{
${ }^{5}$ Stockholm International Peace Research Institute, "SIPRI Military Expenditure Database (1988-2015)," 2015. Retrieved from: https:/www.sipri.org/databases/milex. Accessed May 8, 2016

${ }^{6}$ Sam Perlo-Freeman, Sam, Aude Fleurant, Pieter Wezeman and Siemon Wezeman,"Trends in World Military Expenditure 2015,” 2015, Stockholm International Peace Research Institute Fact Sheet

${ }^{7}$ Ministry of Defense of Japan, "Defense Programs and Budget of Japan: Overview of FY2016 Budget" (provisional translation from Japanese-language original), 2016 Retrieved from: http://www.mod.go.jp/e/d_budget/pdf/280330.pdf. Accessed June 22, 2016

${ }^{8}$ Kim Duk-kim, "Naval Strategy in Northeast Asia: Geo-strategic Goals," Policies and Prospects, 2000.

${ }^{9}$ Franz-Stefan Gady, "What to Expect from Russia's Pacific Fleet in 2015," The Diplomat, 2015. Accessed June 15, 2016: http://thediplomat.com/2015/03/what-to-expect-from-russias-pacific-fleet-in-2015/

${ }^{10}$ Kim Duk-ki Naval Strategy in Northeast Asia: Geo-strategic Goals. p 109.
} 
Generation Borei class ballistic missile submarines, such as the Alexander Nevsky. For Russia, this is especially important against the backdrop of the wide proliferation of nuclear weapons in the region. Yet while large ships capable of strategic deterrence remain arguably the most crucial part of the Russian Pacific Fleet, the Pacific Fleet is circumscribed by a lack of logistical support bases and friendly ports in the region where it can call for replenishment and other logistical necessities. Therefore, the Russian Navy is augmenting its Pacific vessels with support ships that can handle logistical matters, thus enhancing and supporting the Pacific Fleet's ability to operate in the region in a green water capacity $^{11}$. Furthermore, it has begun to install an electronic warfare station in the Sea of Okhotsk.

\section{Recent Endeavors in Ameliorating Japan-Russia Ties}

As a result of both major shifts in Northeast Asia's security landscape as well as concerted efforts from both parties, relations between Japan and Russia have improved dramatically since the days of the Cold War. In the past Japan constituted a critical facet in the United States' security policy toward the USSR by virtue of its position as a US ally on the Soviets' Pacific flank. Yet today Japan and Russia see each other as valuable potential partners. In particular, Japan values Russia as a potential source of energy, while Russia hopes to garner greater amounts of Japanese investment for the development of its Far Eastern regions. In the web of interstate relations in Northeast Asia, the two have one of the healthier bilateral relationships among the other states in the region (compared with China-Japan relations and Japan-ROK ties, for example). Japan and Russia, as Mikheev and Trenin state, don't see each other as major military rivals, but rather could establish a bilateral relationship similar to the post-Cold War security rapprochement between Russia and Germany. As the Germany-Russia relationship has been a major lynchpin of the European security environment, a revitalized Japan-Russia defense connection may serve a roughly similar purpose in East Asia. Not only could Japan and Russia collaborate on state-centric security issues such as balancing China or managing potential security threats from North Korea, but they could also cooperate on issues such as maritime security. Even if Japan and Russia didn't establish a formal security partnership, overt or tacit Russian approval, or at least a lack of public opposition, to Japan's endeavors to re-assert its military prowess is important for the realization of Tokyo's security goals. ${ }^{12}$ The evaporation of the Soviet threat toward Japan opened up opportunities for greater Japan-Russia rapprochement after the Cold War, although this prospect was largely torpedoed, due in part to domestic pressures in Japan and Russia.

The Japanese and Russian governments, outside of the Kurils/Northern Territories issue have been working hard to build stable and equitable security relations with each other. Moscow and Tokyo have regularly held the so-called $2+2$ meetings, which are bilateral meetings between Japan and Russia's foreign and defense ministers. These meetings have multiple purposes, including reducing Cold War-era hangovers of strategic

\footnotetext{
11 John C. K Daly, “Russia’s Pacific Fleet Receives New Ships, Missions," Eurasia Daily Monitor, Volume, 11 Issue, 47, 2014.

${ }^{12}$ D. Trenin and V. "Mikheev, Rossiya i Yaponiya kak resurs vzaimogo razvitiya: vzglyad iz XXI v. na problemu XX v. M," Mosk. tsentr Karnegi (Russia and Japan as a Source of Mutual Development: A view from the 21st century at a Problem from the 20th Century, Moscow Carnegie Centre, 2007.
} 
mistrust between the two countries, developing greater mutual understanding of the Northeast Asian strategic environment, and laying the groundwork for a more formal, institutionalized framework for Russo-Japanese security cooperation. Despite the fact that Moscow and Tokyo have established meetings including both their respective foreign and defense ministers, a discrepancy in viewpoints and interests persists on the Russian end, making it difficult for Moscow to create a cohesive policy vis-à-vis Tokyo over this issue. A strong divide within the Russian government itself has further accentuated this problem. The ostensibly strong central authority inherent in President Putin's administration notwithstanding, the Russian foreign and defense ministries lack a cohesive and coordinated policy stance toward Japan. The Russian foreign ministry is keen to improve relations with Tokyo, yet the Russian defense establishment tends to focus on issues such as the perceived military and strategic value of the Kuril Islands/Northern Territories.

\section{The Perennial Kuril Islands/Northern Territories Dispute}

The efforts of the Japanese and Russian governments to improve bilateral ties notwithstanding, the seemingly intractable dispute between the two countries over the Kuril Islands/Northern Territories has proven to be a consistent ill in the overall bilateral relationship between Moscow and Tokyo. Russo-Japanese security relations, particularly vis-à-vis the contested island chain, have been in a state of flux since 2010 . That year, thenserving Russian president Dmitiri Medvedev visited Kunashir Island, drawing the ire of the government in Tokyo. The accession of Vladimir Putin to the Russian presidency again in 2012 marked a thaw in relations between Moscow and Tokyo. Relations cooled starting in 2014 as Japan joined other countries in condemning Russia's annexation of Crimea.

One perspective asserts that it is a lack of incentive that keeps the Japan-Russia dispute festering, namely because the importance in which Russia holds Japan as a partner for economic and energy remains relatively limited and that there is no sense of urgency on the part of the Russians to resolve the dispute ${ }^{13}$. The bilateral dispute over territory however has not prevented Japan and Russia from being able to cooperate on a host of issues ranging from threats to regional stability (such as conflicts in Afghanistan and the Middle East) to other non-traditional security issues such as economic security and terrorism ${ }^{14}$. Even after relations cooled in light of the crisis in Ukraine from 2014, the two sides managed to come together again in a spirit of cooperation in response to North Korea's fourth nuclear test, its orbital rocket launch as well as the launch of a Musudan medium range missile in 2016.

Japanese policy officials such as Kazuhiko Togo have called for the territorial issue between Japan and Russia to be placed on the back burner of their bilateral relations, and for the issue to be the end result of closer bilateral ties, as opposed to a requirement for the establishment of a sound bilateral relationship ${ }^{15}$. If, therefore, Japanese officials perceive

\footnotetext{
${ }^{13}$ Stephen Blank, "Sino-Russian Relations and the Failure of Russo-Japanese Relations," The Asan Forum, 2015. Retrieved from: http://www.theasanforum.org/sino-russian-relations-and-the-failure-of-russojapanese-relations/. Accessed January 12, 2016.

${ }^{14}$ D. Trenin and V Mikheev, "Rossiya i Yaponiya kak resurs vzaimogo razvitiya: vzglyad iz XXI v. na problemu XX v. M."

${ }^{15}$ Marina Sharko, "Prospects of Cooperation of Russia and Japan in the Asia Pacific Region," International Journal of Business and Social Science, Volume, 5, Number, 9(, Issue 1, 2014.
} 
that the unresolved quarrel is causing Japan to lose opportunities to build a greater rapprochement with Russia, then this may coax Japan even more into setting aside the ails in its relationship with Russia, and instead focus on the positive, constructive aspects of the relationship. Even Japan's nationalist Prime Minister Shinzo Abe has taken a particular interest in resolving this bilateral issue between the two sides. Abe, whose strategy has thus far been to rely on his personal relationship with Vladimir Putin, has taken special efforts to negotiate with Russia at the expense of political capital. If, as Brown argues, Abe were not truly serious about resolving the issue, but rather were doing it just for political show, then he could have enacted the negotiations he has thus far at even less cost to his political capital. Particularly given the catalogue of failures from past Japanese heads of government to effectively end the deadlock, Abe's consistent and willful efforts underscore certain earnestness on his part to truly reach an understanding with Russia, even if this means reaching such an accord on less-than-ideal terms ${ }^{16}$.

Nevertheless, Russia, which currently administers the Kuril Islands/Northern Territories, has taken actions that have drawn disdain in Tokyo. Japanese officials have expressed exasperation at Russian announcements regarding the militarization of some of the contested islands, including announcements in the spring of 2016 of Russia's "unprecedented" upgrade of its military infrastructure on the islets. Russia's announcement in the spring of 2016 stating its intention for further military buildup on the island chain (including the installation of missiles) has placed even more stress on this particular aspect of Japan-Russia relations. Moscow's designs over the territories allegedly drew surprise of Japanese officials. Japanese lawmakers have generally been unable to refrain from denouncing Russia's occupation of the islands as illegal, which is invariably met with a harder line from the Russian government.

One potential solution to this continuous dispute is the establishment of a "parallel" system between Japan and Russia, whereby the Kuril Islands/Northern Territories issue is compartmentalized to such an extent that it is treated separately from other issues on which Japan and Russia have a greater ability to cooperate. To be sure, the lack of resolution on this affair has so far only worked to the detriment of Japan and Russia in preventing them from realizing the full fruits of their potential cooperation ${ }^{17}$. Nevertheless, the Japan-Russia bilateral relationship is not such that it is contingent upon the resolution of this dispute, and at worst constitutes an ongoing irritant rather than a major security threat for either country.

\section{Same Concern, Different Perspectives: Rise of China's Military Power}

The lack of agreement between Japan and Russia over their contested territories, while a major factor in Japan-Russia security ties, is not the only major concern for the two countries' security in Northeast Asia. After the fall of the USSR, perhaps the biggest geopolitical shift in Northeast Asia affecting Japan-Russia ties is the rise of China's military. With approximately 14,500 kilometers of coastline, one of China's primary goals has been to assert itself as a maritime power. China's thrust for greater maritime capacity bring it in contact with several maritime powers, in both the South China Sea and the East

\footnotetext{
${ }^{16}$ James Brown, "Abe's 2016 Plan to Break the Deadlock in the Territorial Dispute with Russia," The AsiaPacific Journal - Japan Focus, Volume 14, Issue 4, Number 1, February 2016.

${ }^{17}$ D. Trenin and V Mikheev, "Rossiya i Yaponiya kak resurs vzaimogo razvitiya: vzglyad iz XXI v. na problemu XX v. M.”
} 
China Sea, as well as the East Sea/Sea of Japan. Though China publicly touts its "peaceful rise", its growing assertion of power has prompted neighboring maritime powers in Northeast Asia to respond in kind.

While China does not have the same geopolitical or strategic designs for Northeast Asia as it does in the East China Sea or South China Sea, China nevertheless seeks the freedom of navigability into areas that are part of the common maritime zones of Japan and Russia. One of China's central maritime priorities in Northeast Asia is accessibility to and unfettered navigability through the Korea Strait ${ }^{18}$. This area lies in a zone of contention between Japan and the Republic of Korea, and is also a major waterway serving as abridge for the US 7th fleet between its home base in Yokohama, Japan and the US Navy Korea basing installation at Jinhae.

Of particular importance to the PLAN is an emphasis on the use of submarines, particularly nuclear submarines, for China's prospective offshore and blue water capabilities. The People's Liberation Army Navy (PLAN) has been focusing especially on building up its East Sea Fleet and South Sea Fleet, marking a shift in priorities from the Cold War when the North Sea Fleet was the lynchpin of Chinese maritime security. The focus on the East Sea Fleet is based on the possibility of a conflict over Taiwan, while the main purpose of building up the South Sea Fleet is the preservation of China's maritime sovereignty ${ }^{19}$. Nevertheless, China's North Sea Fleet, which is of most immediate consequence for both Japan and Russia, remains an integral aspect of China's maritime security. The People's Liberation Army Navy has been increasing its number of Jin-class nuclear-powered ballistic submarines, although uncertainty remains as to whether they will be used for at-sea patrols or will be kept closer to the Chinese mainland. The Federation of American Scientists has reported at least five recent sightings of Jin-class SSBNs near North Sea Fleet installations ${ }^{20}$.

Furthermore, the North Sea Fleet has recently upgraded its importance for Chinese homeland defense. In early 2016 the Chinese government announced a rearrangement of China's old military command structure, placing the North Sea Fleet in Central Command, tasked with defending the Chinese capital, Beijing. According to an anonymous source, the North Sea Fleet under Central command will be tasked with managing potential threats from Japan, North Korea and Russia ${ }^{21}$. Chinese defense officials have taken steps to augment the North Sea Fleet's capabilities such as adding new anti-submarine turboprops. The PLAN's sole operational aircraft carrier, the Liaoning is based at the North Sea Fleet's headquarters in Qingdao, although it is not under the command of the North Sea Fleet, but rather operates under the immediate direction of naval headquarters. Chinese naval planners are working to increase the Chinese maritime forces' number of both nuclear-

\footnotetext{
${ }^{18}$ Shi Chunlin and Li Xiuying, "The Security Issue of the Korea Strait and China's Strategic Countermeasures," Dongjiang Journal, Issue 4, 2014.

${ }^{19}$ Office of Naval Intelligence, "The People's Liberation Army Navy: A Modern Navy with Chinese Characteristics," Federation of American Scientists, 2009.

${ }^{20}$ Hans Kristensen, "China SSBN Fleet Getting Ready - But For What?" Federation of American Scientists, 2014. Retrieved from: https://fas.org/blogs/security/2014/04/chinassbnfleet/. Accessed June 17, 2016.

${ }^{21}$ Minnie Chan and Zhen Liu, “China's North Sea Fleet put under Central command to help safeguard the capital," South China Morning Post, 2016. Accessed: June 19, 2016. http:/www.scmp.com/news/china/diplomacy-defence/article/1908768/chinas-north-sea-fleet-put-undercentral-command-jinan
} 
powered and diesel-electric submarines, and are working on building a submarine facility in Liaoning Province ${ }^{22}$.

Japan faces the rise of China's military power with growing skepticism. For Japan, one of the most pressing concerns is the Diaoyu/Senkaku Islands dispute. China covets the islands for their energy deposits. Furthermore, China-Japan relations remain soured by bitter historic memories of Japanese activities in China during World War Two. After a brief administration by the Democratic Party of Japan, the long-governing Liberal Democratic Party took control of the Japanese Diet in 2012, under the leadership of Shinzo Abe's who has undertaken policy stances widely perceived to be nationalistic in nature. The return of the Liberal Democrats to Japanese leadership came at a time of worsening relations between Japan and China. When Chinese ships began to encroach upon the disputed Diaoyu/Senkaku islands, Japan asserted that it would not hesitate to resort to military force to defend them. Likewise, Japan and the United States both refused to heed Chinese requests to cease joint Japan-US military exercises during a China-US summit in $2013^{23}$. Since then, there have been numerous incidents between China and Japan's militaries, including Chinese air force intrusions into Japan's Air Defense Information Zone.

Russia also remains wary of Chinese intentions, and is especially concerned about becoming the subordinate actor in the China-Russia relationship. Similar to Japan, one of the primary drivers of Russia's attempts to amplify its Asian maritime capabilities is the buildup of the Chinese navy ${ }^{24}$. Some of Russia's more Western-oriented policy figures (who are in the minority in the Kremlin) believe that Russia should align itself more closely with Japan as part of a network of democracies in Asia designed to balance against China. This policy stance stems in part from a fear that Russia is depending too heavily on China in its Asian political orientation, and the realization in Moscow that as Chinese naval power continues to increase, Russia will need security partners to counter the potential threat that a greater Chinese strategic presence may have in the Russo-Japanese maritime commons. Select Russian officials also consider that the upgrading of Russia's Pacific fleet will not only enhance its Asian defense capabilities against the rise of China, but it will also allow Russia to act as a "third power' in regions outside of its immediate areas of interest that nevertheless pertain to China, such as the disputed Diaoyu/Senkaku islands. ${ }^{25}$

\section{Effects of Japan and Russia's Respective Responses to China on Moscow-Tokyo Defense Relations}

\footnotetext{
${ }^{22}$ Nuclear Threat Initiative, “ China's Submarine Capabilities,” 2015. Retrieved from: http://www.nti.org/analysis/articles/china-submarine-capabilities/. Accessed June 28, 2016.

${ }^{23}$ D. V. Strel’tsov, “Kachestvennyye sdvigi politiki Yaponii v sfere voyennoy bezopasnosti”, v 2013 g. Vestnik MGIMO Universiteta, 5 (32) (Qualitative Shifts in Japan's Policy in the Military Security Sphere). Vestnik MGIMO University, Volume, Issue 5 (32), 2013.

${ }^{24}$ Yoshiaki Sakaguchi, Director Policy Studies Department, National Institute for Defense Studies (Japan), "Briefing memo: Russia's Military Reform and the Navy, 2013

${ }^{25}$ Petr Yur'evich Samoylenko, "Strategicheskiye interesy Rossii v ATR: sinergeticheskiy i informatsionnoimidzhevyy faktory v voprosakh voyennoy i ekonomicheskoy integratsii Oykumena,". Regionovedcheskiye issledovaniya, 2014 (Russia's Strategic Interests in the Asia-Pacific Region: Synergetic and InformationalImage Factors in Questions Of Military and Economic Integration Of The Ecumene. Regional Studies Research)
} 
In terms of cooperation, information exchange and interoperability, defense relations between Japan and Russia remain relatively poor, mostly due to a lack of formal arrangements aimed at fostering greater cooperation and exchange. Officials in both Moscow and Tokyo seem to be aware of this, and have expressed concerns over the potential problems that could arise if such a culture of exchange and cooperation is not established. It would stand to reason, according to Graeme Auton, that Japan would seek closer coordination of security with Russia not only due to the rise of China and the continual threat from North Korea, but also because of the "relative decline" of the US in Northeast Asia ${ }^{26}$. Russia also seeks to instate a greater level of collaboration on maritime security with Japan, as well as the United States by extension as a major security partner for Japan. Although Japan and Russia have not signed a peace treaty formally ending the dispute between the two countries over the various islands in question, the Japanese elite political establishment does not have any intention of using military power against Russia in order to resolve the dispute, at least in the short term ${ }^{27}$.

Despite Tokyo's aforementioned misgivings regarding Russian military activities and posturing on and around the contested islands, Japanese officials have expressed understanding views on some of Russia's military activities in East Asia. Russia has continued to engage in show of force activities such as encroachments into Japanese airspace near the Kuril Islands/Northern Territories. The Japanese defense establishment, however, has not reacted to such Russian military activities with overt hostility. Japanese commanders understand that, given the relative recentness of the military overhauls in the Russian Far East, Russia needs to test its capacities and operability in the region. Furthermore, Japanese defense officials have often seen Russian maneuvers as being a reaction to recent developments in Chinese military capacity and strategy. Japan and Russia, in fact, have implemented an agreement on cooperation between the Russian Security Council and the Japanese foreign ministry, per an agreement signed when Russian security chief Nikolai Patrushev visited Tokyo in October, $2012^{28}$.

Nevertheless, tensions between Japan and Russia beyond their territorial quarrel remain. It is unlikely that Japan and Russia would coalesce their forces in any meaningful to balance China. Tensions and misgivings in the China-Russia defense relationship are a normal and natural part of ties between two great powers attempting to assert their own interests simultaneously in a given region. Despite nagging mistrust, China and Russia have engaged in numerous military drills in East Asia, such as "Joint Sea 2015 II". Any attempt by Japan and Russia to combine forces against China would most likely only cause a stronger and more aggressive stance from Beijing. While both Japan and Russia remain concerned regarding Beijing's augmenting defense prowess, it is not necessarily an area of shared concern for Japan and Russia per se, as the two countries have differing specific concerns about China's rise. Furthermore, any supposition that Japan and Russia would unite to balance or deter China exists under the assumption that China and Russia's

\footnotetext{
${ }^{26}$ Graeme Auton, "Japan, Russia and the Northern Territories Dispute: Reflections on an Evolving Northeast Asian Balance of Power," Japan Studies Association Journal, Volume 9, 2011.

${ }^{27}$ Mikhail Gatsko, "Vneshniye ugrozy voyennoy bezopasnosti Rossii” (External Threats to Russia's Security) Obozrevatel'-Observer, 10-C, Number 4, 2006.

${ }^{28}$ C. Pajon, “Japon-Russie: Vers Un Rapprochement Stratégique?” (Japan-Russia: Toward a Strategic Rapprochement?). Russie Nei Visions, Number 72, 2013.
} 
rapprochement is incapable of extending into increased levels, however imperfect, of mutual trust and partnership in Northeast Asia.

Japan and Russia continue to experience broader strategic mistrust in the region. Japanese naval power remains an important consideration for Russia's Pacific maritime forces. The Russian Pacific Fleet's designated area of responsibility for defending Russia's commercial interests surrounds both Japan and South Korea ${ }^{29}$. Potential reasons for a Japan-Russia military conflagration include not only the possibility, however remote, of a conflict over the disputed islands themselves, but also in a potential clash over maritime natural resources ${ }^{30}$. As Japan continues to place large priority on its economic stature as a means of exercising power, Russian attempts at increasing its own economic prowess in the Asia-Pacific could lead to more conflicts of interest between Japan and Russia in the economic sphere.

Japan and Russia's diligent efforts towards increased rapprochement, as well as the separate but shared concern over the rise of China, are not sufficient to foster closer JapanRussia security cooperation in such a way that would allay or prevent a rise in Japan-Russia strategic tensions once again. Rather, Japan and Russia's policy shifts and military revivals, while partially spurred by the rise of China, could in fact exacerbate tensions, or at the very least cause mistrust between the two countries to linger, if not calcify into a long-term state of misgivings about the other country's capabilities or intentions (despite or perhaps because of the current lack of urgency to resolve their outstanding dispute). This is particularly true as the two countries are clustered together in a tense neighborhood, as well as the state of coexistence, if one employs the use of primary institutions in analyzing Japan-Russia defense ties, between the two states. While the two countries are not deadlocked in the power struggle form regional primacy that may create a situation of power political, the lack of a cooperative or even convergent basis for the two countries' bilateral ties means that growing militarization risks augmenting tensions. It would make little sense for either Japan or Russia not to view askance each other's respective military rise.

Compounding the lingering security tensions between Japan and Russia is the role of the US alliance with Japan, in such a way that goes beyond the traditional implications of Japan's role as providing the US the ability to project power near Russia's Pacific regions. The Japan-US alliance has evolved from focusing primarily on bilateral defense to promoting overall stability in the Asia-Pacific region ${ }^{31}$. The aforementioned recent shifts in Japanese defense policy, combined with the Japan Self Defense Forces' enhancement of its technical capabilities will further empower Japan both for its own defense as well as assisting the United States in accordance with the requirements of the alliance. While the Japan-US military alliance serves a Russian interest in keeping Chinese military power in

\footnotetext{
${ }^{29}$ V. Vysotskiy, "Morskoy shchit Rossii. Voyennaya mysl,” (Russia's Maritime Shield. Military Thought) Volume 1, Issue 3-12, 2012.

${ }^{30}$ E. Bogatyrev and V. Malyshev, “Analiz Voyennykh ugroz natsional'noy bezopasnosti Rossii i ikx vliyaniye na planirovaniye meropriyatiy grazhdanskoy oborony.” Strategiya grazhdanskoy zashchity: problemy i issledovaniya, 4(2) (An Nnalysis of Russia's National Security Threats and their Influence on the Planning Measures of Civil Defense, The Strategy of Civil Defense), 4(2), 2014.

${ }^{31}$ Svetlana Vladimirovna Buldaeva, "Rol' yapono-amerikanskogo al'yansa bezopasnosti na sovremennom etape i posledstviya dlya Rossii" (The Role of the Japanese-American Security Alliance at its Current Stage and Implications for Russia). Molodoy uchenniy, 90, 2015.
} 
check, the Japan-US defense partnership also runs contrary to Russian interests ${ }^{32}$. Contrarily, China's military rise, despite the vexation that it has caused defense officials in Moscow, also helps to assuage Russian fears of a joint Japan-US dominance over East Asian security affairs ${ }^{33}$. In particular, Japan's aforementioned defense policy revisions could potentially bring Japan to the US's aid in the case of hostilities between Russia and the United States, particularly in Northeast Asia.

The extent to which recent developments in Japan and Russia's respective defense policies will harm or hinder Russo-Japanese security ties will depend on two main factors. The first is the extent to which Japan and Russia can deepen their communication and confidence building on defense affairs. As resolution of Japan and Russia's island quarrel seems to be a distant prospect at best, continued interchange, if not collaboration on security, is necessary to prevent mishaps or a worsening of strategic tensions. The second factor is the extent to which Russia chooses to grow closer to China in the security realm. If Russia chooses to sidle closer to China as developments in China, Japan and Russia's respective military capabilities and policies continue to evolve, then this could place further strain on Japan-Russia ties. Russian defense and policy officials will likely calculate their policies toward strengthening ties with China or Japan based in part on how much of a threat to Russia's interests Japan's military shifts pose, as well as the extent to which the Japan-US alliance harms Moscow's interests in the Asia-Pacific.

\section{Conclusion}

The coincidental development of a revision in Japan's defense policy as well as Russian endeavors to revitalize its military prowess in the Asia-Pacific, will likely have a significant effect on Northeast Asia's security environment. There is a possibility that simultaneous shifts in Japanese and Russian military policies could negatively affect the balance of military power in Northeast Asia. A lack of communication and understanding between the two sides poses the risk of further regional fragmentation. Much of this will likely be contingent upon Japan and Russia's ability to compartmentalize more problematic issues in their relationship, such as the ongoing territorial dispute over the Kuril Islands/Northern Territories, while being able to cooperate more closely on areas of mutual interest.

Aside from the strictly bilateral issues inherent in defense and security relations between Moscow and Tokyo, several other complicating factors, such as the rise of Chinese power will further augment the considerations with which officials in Moscow and Tokyo will have to contend. While Japanese and Russian defense policies will be developed according to their own respective interests vis-à-vis China's military stance, this reality represents one of the most important factors in the recent military developments undertaken in Moscow and Tokyo. Even if Japan and Russia do not establish a coordinated position on China, Japan and Russia's own defense shifts in response to augmented Chinese power will also have important reverberations for the Japan-Russia bilateral defense relationship.

\footnotetext{
${ }^{32}$ Sergei Vladimirovich Volkov, "Vzaimootnosheniya SShA i Yaponiya: vzglyad iz Rossii" (The US and Japan's Relations - a view from Russia). Vlast 2, 2014.

${ }^{33}$ V. I. Balakin, "Rossiya v Vostochnoaziatskom Regione” (Russia's Role in the East Asian Region). Znaniye. Ponimaniye. Uchenie, 2014.
} 